\title{
CORRIGENDUM
}

Genes \& Development 18: 1533-1538 (2004)

\section{Corrigendum: Regulation of the TSC pathway by LKB1: evidence of a molecular link between tuberous sclerosis complex and Peutz-Jeghers syndrome}

Michael N. Corradetti, Ken Inoki, Nabeel Bardeesy, Ronald A. DePinho, and Kun-Liang Guan

It has recently come to the authors' attention that two panels in Figure 5A were duplicated. The original digital images for this figure could not be located; however, we believe that this duplication was caused by an inadvertent error during figure preparation. To correct this mistake, the lower duplicated panels in Figure 5A have been removed, as shown below. This modification has no effect on the conclusion of the paper, as data in Figure 5B similarly demonstrate that the LKB1 mutant cells were more sensitive to glucose starvation. The authors apologize for this error.

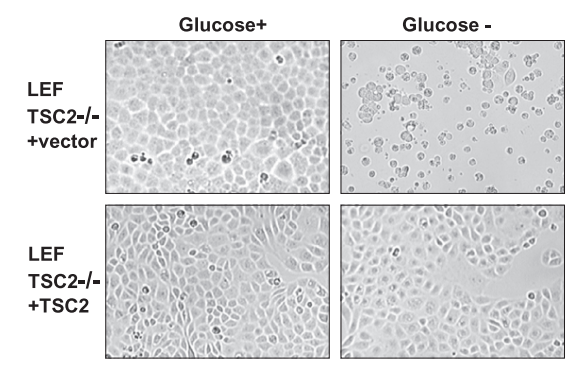

doi:10.1101/gad.324970.119 


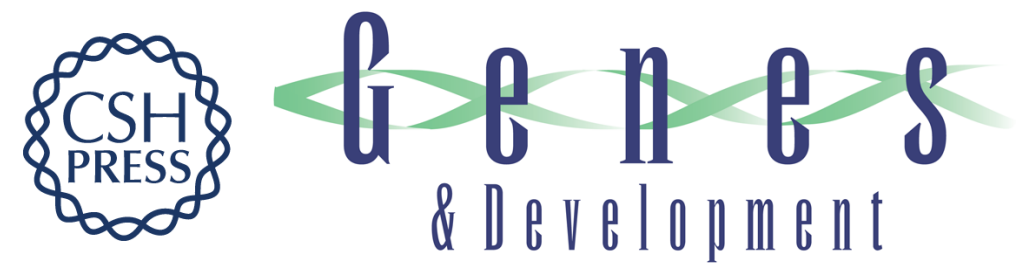

\section{Corrigendum: Regulation of the TSC pathway by LKB1: evidence of a molecular link between tuberous sclerosis complex and Peutz-Jeghers syndrome}

Michael N. Corradetti, Ken Inoki, Nabeel Bardeesy, et al.

Genes Dev. 2019, 33:

Access the most recent version at doi:10.1101/gad.324970.119
Related Content Regulation of the TSC pathway by LKB1: evidence of a molecular link between tuberous sclerosis complex and Peutz-Jeghers syndrome
Michael N. Corradetti, Ken Inoki, Nabeel Bardeesy, et al.
Genes Dev. July , 2004 18: 1533-1538

\section{License}
Email Alerting
Service
Receive free email alerts when new articles cite this article - sign up in the box at the top right corner of the article or click here.

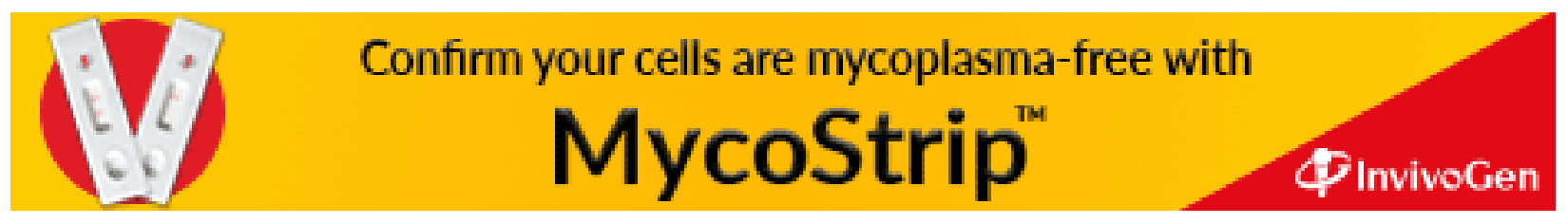

